\title{
NOTE
}

\section{Growth response of the seagrass Cymodocea nodosa to experimental burial and erosion}

\author{
Núria Marbà, Carlos M. Duarte \\ Centre d'Estudis Avançats de Blanes-CSIC, Cami de Santa Bàrbara s/n, E-17300 Blanes (Girona), Spain
}

\begin{abstract}
The response of Cymodocea nodosa (Ucria) Aschers. seedlings to experimental burial and erosion was examined to test the extent of coupling between fluctuations in sediment depth and seagrass growth. Shoot survivorship declined with erosion and with increasing burial depth, relative to the controls. Seagrass growth response, described by changes in internodal and leaf sheath length, the rate of appearance of new leaves, and shoot vertical growth showed a bell-shaped response to fluctuations in sediment depth. Shoot internodal and leaf sheath length, the rate of appearance of new leaves, and vertical growth all increased with sediment depth from minimal values under erosion to maximal values at burial of $<7 \mathrm{~cm}$. These results demonstrate that C. nodosa seedlings tolerate burial $<7 \mathrm{~cm}$, and that burial stimulates the growth of surviving seedlings. Examination of this growth response for $C$. nodosa and other seagrass species, which allows quantification of tolerable changes in sediment depth, may provide useful information for conservation of seagrass populations.
\end{abstract}

KEY WORDS: Seagrass growth - Sand burial - Sand erosion Cymodocea nodosa. Seedlings

Seagrasses develop extensive meadows on sandy coastal areas around the world, where they often experience intense sediment dynamics. Seagrass species that develop vertical shoots (e.g. Cymodocea, Thalassia, Thalassodendron) may respond to fluctuations in sediment depth by modifying their vertical growth to relocate their leaf-producing meristems closer to the new sediment level, leading to a coupling between fluctuations in sediment depth and seagrass vertical growth (Patriquin 1973, Boudouresque et al. 1984, Marbà et al. $1994 \mathrm{a}, \mathrm{b})$. A coupling between fluctuations in sediment depth and plant growth, similar to that postulated here for seagrasses, has been demonstrated for rhizomatous coastal dune plants (e.g. Marshall 1965, Wallen 1980, Eldered \& Maun 1982, Disraeli 1984, Maun \& Lapierre 1984, Zhang \& Maun 1990).
While the response of coastal dune plants to fluctuations in sediment depth has been well documented, this knowledge is mostly qualitative for seagrasses, and there are, as yet, few detailed quantitative reports on the response of seagrasses to burial and erosion (e.g. Patriquin 1975, Marbà et al. 1994a, b). This response must be, however, an important component of their adaptation to their sandy substrate, and may be important in forecasting seagrass dynamics in coastal areas subject to significant erosion or accretion rates, and to establish the limits to the siltation and erosion rates seagrasses tolerate.

We report here the response of seagrass Cymodocea nodosa (Ucria) Aschers. to fluctuations in sediment depth based on experimental manipulations.

Methods. We harvested about 200 Cymodocea nodosa seedlings and sediments from a shallow $(-0.5$ to $-1.0 \mathrm{~m}$ ) sandy littoral in Alfacs Bay (Ebro Delta, NE Spain) in July 1992. We preferred seedlings as experimental units because, unlike shoots from mature plants, they can be collected without damaging their rhizomes and are self-contained units, independent of each other. The seedlings collected had sprouted in 1992, and had produced between 5 and 10 leaves at the time of collection. The collected seedlings were transported to the laboratory where they were exposed to manipulations in sediment depth.

The experimental design included 8 levels of sediment depth relative to the leaf-producing meristem: erosion (sediment surface just below the rhizome); sediments maintained at the meristem level (the relative position they had in the field, i.e. 0 burial); and burial of $1,2,4,7,13$, and $16 \mathrm{~cm}$ above the meristem. Each treatment consisted of 7 replicate seedlings to which the treatments were independently applied. The range of sediment depths tested were selected to encompass the range of burial and erosion observed in littoral 


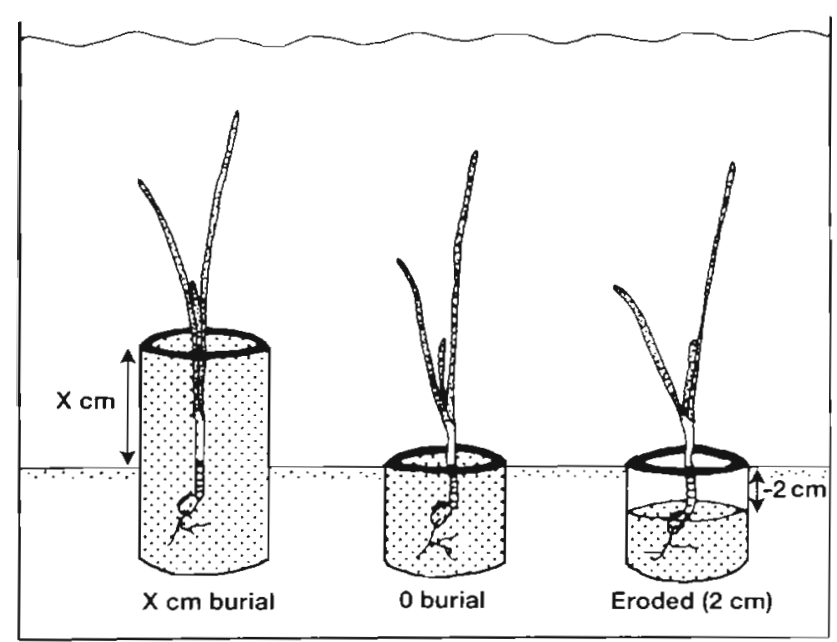

Fig. 1. Schematic representation of the experimental design used to examine the response of seagrass seedlings to altered sediment depth

zones supporting Cymodocea nodosa (Marbà et al. 1994a). Because most seedlings had 2 vertical shoots, the 7 replicate treatments involved a total of 103 , rather than 56 , shoots.

Since seagrasses have been shown to be nutrient limited in Alfacs Bay (Pérez et al. 1991), we avoided confounding nutrient effects in the experiment by amending the sediments with nutrients. This was done by inserting 7 slow-release mixed fertilizer sticks in the sediments, representing a loading of about $7.6 \mathrm{~g} \mathrm{~N} \mathrm{~m}^{-2}$ and $1.04 \mathrm{~g} \mathrm{P} \mathrm{m}^{-2}$, prior to sowing the seedlings in 2 aquaria (50 cm long $\times 32 \mathrm{~cm}$ width $\times 35 \mathrm{~cm}$ height). This nutrient loading has been shown to prevent nutrient limitation in this seagrass population (Pérez et al. 1991). Seedlings were randomly assigned to the treatments and to either of the 2 experimental aquaria, so that seedlings subject to all of the treatments were represented in both aquaria. By applying the treatments independently to each replicate seedling and assigning them randomly to each of the 2 aquaria we ensured a proper design and replication. Seedlings were maintained in running sea water (about $3 \mathrm{~d}$ renewal time) at $20^{\circ} \mathrm{C}$ and an irradiance of $500 \mu \mathrm{mol} \mathrm{m} \mathrm{m}^{-2} \mathrm{~s}^{-1}$ in a 12 h day $12 \mathrm{~h}$ night photoperiod. The seedlings were planted so that the leaf-producing meristem was just at the sediment surface, the position they adopt after seedling sprouting (Marbà unpubl. data). We allowed the seedlings to acclimate to experimental conditions for $5 \mathrm{~d}$ before marking the shoots by punching a hole through the leaves just above the leaf sheath with a needle (cf. Pérez et al. 1991). Leaves were punched in order to measure the rate of appearance of new leaves on the shoots, which is closely related to leaf growth (Brouns 1985).

Treatments were then imposed by enclosing the roots and rhizomes of each individual seedling within a $5 \mathrm{~cm}$ diameter opaque PVC cylinder. The cylinders extended from just below the roots to a height above the sediment equivalent to the corresponding treatment and were filled with sediments (Fig. 1). The control seedlings (i.e. 0 burial) were also enclosed within PVC cylinders. The seedlings were then allowed to grow for $35 \mathrm{~d}$, slightly longer than the annual average time in between production of 2 consecutive leaves in a Cymodocea nodosa shoot in this area (26 d; Duarte \& Sand-Jensen 1990), before harvesting. We then counted the number of surviving shoots (i.e. those with standing green leaves) and the number of new leaves they produced. We also measured the length of the leaf sheath and the youngest vertical internode on each surviving shoot, which is the one showing the greatest response to changes in sediment depth (Marbà et al. 1994a). The youngest vertical internodes appeared prior to the experiment, but elongated during the study. Shoot survivorship was recorded as a binomial variable, taking the values of 0 and 1 for dead and surviving shoots respectively.

Seedling response to experimental burial and erosion was evaluated using analysis of variance (ANOVA). Some of the variables were square-root transformed prior to the analysis, which was found to be necessary to homogenise their variance (Sokal \& Rohlf 1981). The significance of pairwise compari-

Table 1. Cymodocea nodosa. Analyses of variance of the parameters measured on seagrass seedlings after treatments. Similar treatment responses (Tukey's HSD analysis) share a common underline. No. of observations for all variables $=102$

\begin{tabular}{|c|c|c|c|c|}
\hline Variable & $\mathrm{r}$ & $F$ ratio & $\mathrm{p}$ & Treatment $(\mathrm{cm})$ \\
\hline Shoot survival & 0.76 & 18.62 & $<0.00001$ & $\begin{array}{llllllll}-2 & 0 & 1 & 2 & 4 & 7 & 13 & 16 \\
\end{array}$ \\
\hline Internodal length ${ }^{\circ}$ & 0.53 & 5.35 & $<0.00001$ & $\begin{array}{llllllll}-2 & 0 & 1 & 2 & 4 & ? & 13 & 16\end{array}$ \\
\hline Leaf appearance rate & 0.49 & 4.28 & $<0.0005$ & $\begin{array}{llllllll}-2 & 0 & 1 & 2 & 7 & 13 & 16 & 4\end{array}$ \\
\hline Vertical rhizome growth rate & 0.48 & 3.97 & $<0.001$ & $\begin{array}{llllllll}-2 & 0 & 1 & 2 & 7 & 13 & 16 & 4\end{array}$ \\
\hline Leaf sheath length & 0.66 & 10.42 & $<0.00001$ & $\begin{array}{llllllll}-2 & 0 & 1 & 2 & 4 & 7 & 13 & 16\end{array}$ \\
\hline
\end{tabular}




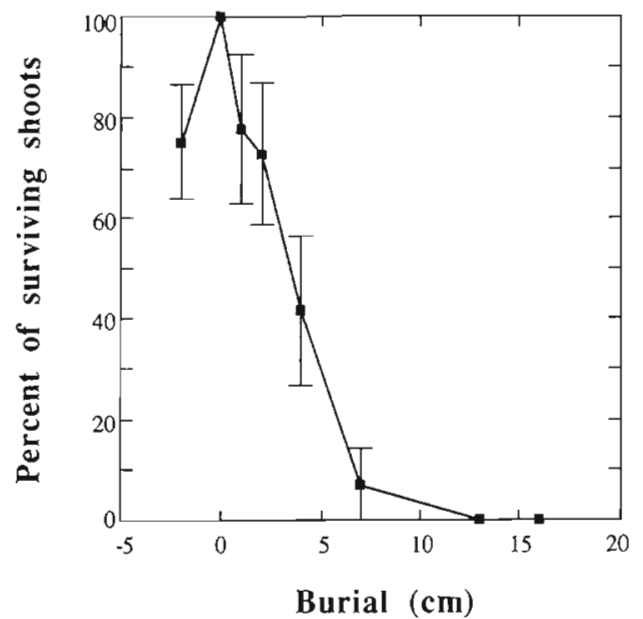

Fig. 2. Cymodocea nodosa. Relationship between shoot survivorship and experimental changes in sediment depth. Values are means $\pm 1 \mathrm{SD}$
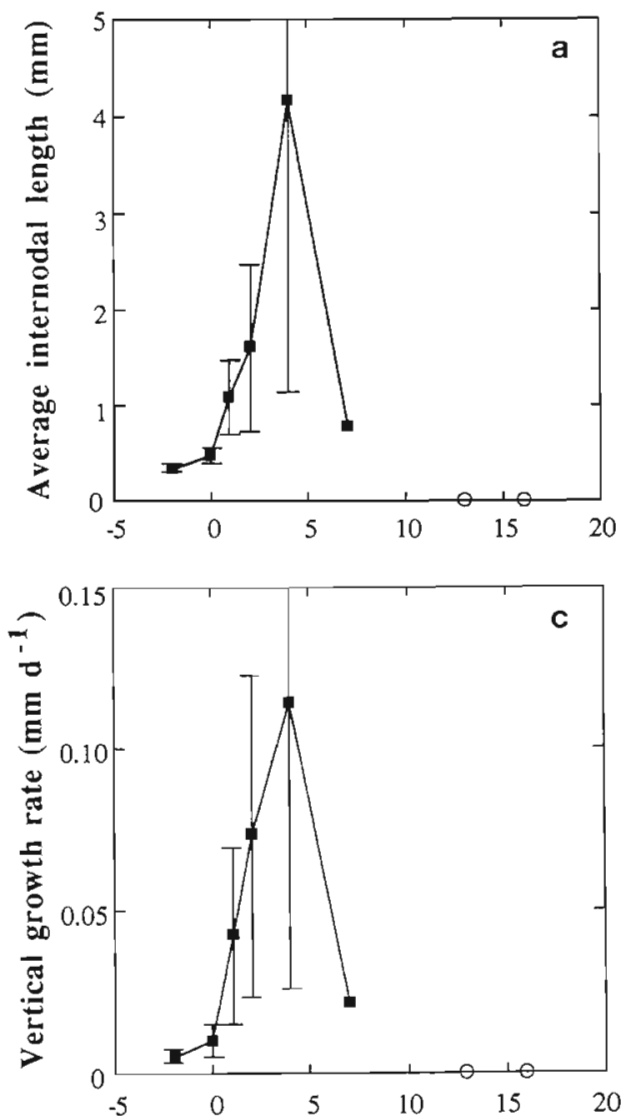

sons between treatments were tested for using Tukey's HSD multiple comparisons test (Sokal \& Rohlf 1981).

Results. The proportion of surviving shoots varied significantly among treatments (Table 1). All shoots survived when the sediment level was not altered (i.e. 0 burial), however, the proportion of surviving shoots decreased significantly as burial depth increased, with no shoots surviving burial $>7 \mathrm{~cm}$ (Table 1, Fig. 2). Survival was also significantly reduced when shoots were exposed to experimental erosion (Table 1, Fig. 2). Although both burial and erosion induced shoot mortality, some Cymodocea nodosa shoots were able to survive burial $<7 \mathrm{~cm}$. The length of the youngest vertical internode produced differed significantly among treatments (Table 1). The average length of the youngest vertical internode ranged between 0.35 and $4.17 \mathrm{~mm}$, and increased as burial increased up to $7 \mathrm{~cm}$ (Fig. 3a). The appearance of new leaves on the shoots also differed significantly among treatments, increasing with burial up to $2 \mathrm{~cm}$ (Table 1, Fig. 3b).
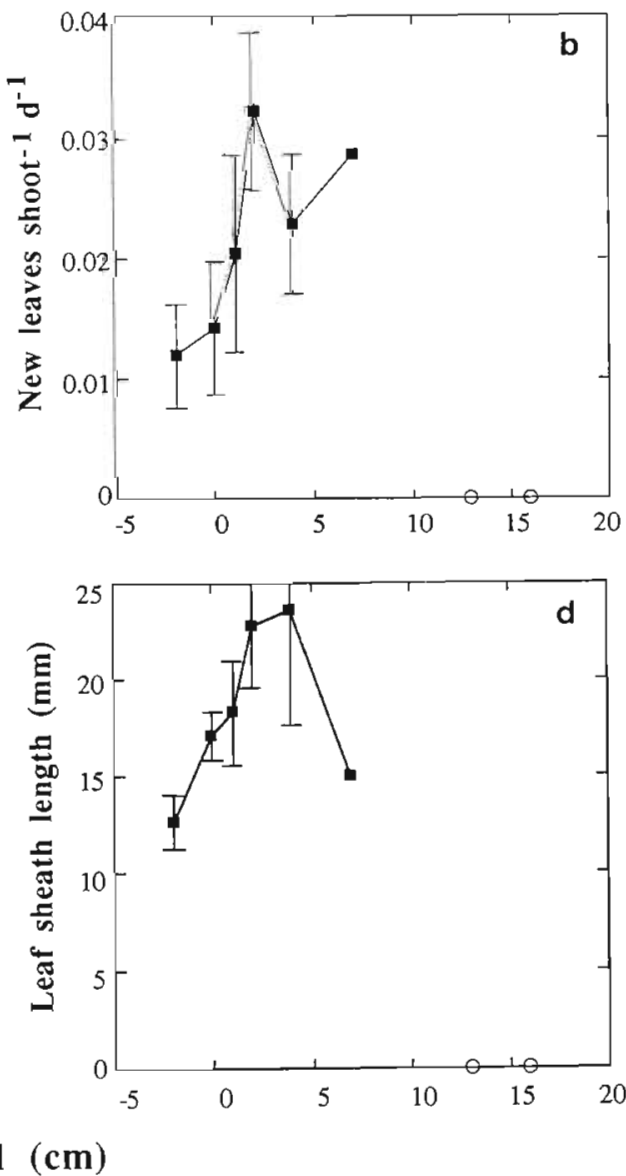

Fig. 3. Relationship between (a) internodal length, (b) the rate of appearance of new leaves, (c) shoot vertical growth, and (d) leaf sheath length of surviving shoots and experimental changes in sediment depth. Values are means \pm 1 SD. Absence of error bar indicates that only 1 shoot survived. (O) No shoots survived the treatments 
Because shoot vertical growth is the product of internodal length and the rate of appearance of new internodes (i.e. $\mathrm{mm}$ internode ${ }^{-1} \times$ internodes $\mathrm{d}^{-1}=\mathrm{mm}$ $\mathrm{d}^{-1}$ ), which equals the rate of appearance of leaves, these results indicate that the vertical growth of shoots exposed to burial $<7 \mathrm{~cm}$ should also increase significantly, as confirmed by our data (Table 1, Fig. 3c). Shoot vertical growth also showed a bell-shaped response to burial, increasing significantly with increasing burial to reach a maximum rate, about 5fold greater than that of the control, when shoots were buried $4 \mathrm{~cm}$. Burial $>7 \mathrm{~cm}$ and erosion lead to reduced vertical growth (Fig. 3c). The increased vertical growth of shoots in response to burial $<7 \mathrm{~cm}$ allowed them to relocate their apical meristems to the sediment surface (Fig. 3c). This relocation should improve the carbon balance of the plants by increasing the leaf surface exposed to light. The response needed to expose the entire leaf surface to ìght following burial was also made possible by the faster elongation of these short shoots (Table 1). The length of the leaf sheaths increased from the short leaf sheaths of shoots exposed to erosion, to maximal lengths with burial of $4 \mathrm{~cm}$; leaf sheath length declined at greater burial depths (Fig. $3 \mathrm{~d}$, Table 1).

Discussion. The results obtained reveal a consistent bell-shaped relationship between sediment depth fluctuations and the performance of Cymodocea nodosa seedlings. This response involved reduced leaf production rate, leaf sheath length and internodal length as a result of erosion and burial greater than $4 \mathrm{~cm}$. Maximal shoot vertical growth and leaf production rate were achieved at intermediate $(4 \mathrm{~cm})$ burial. Hence, intermediate burial (about $4 \mathrm{~cm}$ ) stimulates $C$. nodosa vertical growth, supporting the notion that seagrass vertical growth should be closely coupled to changes in sediment depth (Patriquin 1973, Boudouresque et al. 1984, Marbà et al. 1994a, b). Moderate burial also stimulated leaf growth of the surviving shoots, as reflected in a faster rate of appearance of new leaves (Fig. 3b). This finding is consistent with suggestions that moderate burial stimulates growth of Thalassia testudinum in the Mexican Caribbean (Gallegos et al. 1993). Similar to the results observed here, the increased vertical growth of $T$. testudinum in response to burial involved both a faster rate of appearance of new leaves and the production of longer internodes in the surviving shoots (Marbà et al. 1994b).

However, both erosion and burial resulted in increased shoot mortality relative to the controls; no seedlings survived burial greater than $7 \mathrm{~cm}$. Hence, even though burial up to $4 \mathrm{~cm}$ stimulated leaf growth of the surviving shoots, this may not suffice to compensate for the reduction in production due to parallel increase in shoot mortality. Calculation of the net effect of burial or erosion on seagrass production must, therefore, consider the balance between increased mortality and production. There is evidence, however, that our results may underestimate the response capacity of established Cymodocea nodosa meadows. The reason for this is that seedlings are less vigorous than established plants, as reflected by their thinner leaves ( 1 to $2 \mathrm{~mm}$ compared to 2 to $4 \mathrm{~mm}$ of plants in established meadows) and slower growth rates (plastochrone interval, $\mathrm{PI},=70 \mathrm{~d}$ compared to $26.9 \mathrm{~d}$ of plants in established meadows). Hence established meadows may be able to survive greater burial depth than seedlings, and burial may continue to stimulate $C$. nodosa vertical growth at depths greater than the $4 \mathrm{~cm}$ threshold observed here for seedlings. Indeed, $C$. nodosa shoots within patches are able to survive burial as great as $6 \mathrm{~cm}$, and their vertical growth continues to increase up to those burial depths (Marbà \& Duarte unpubi.). Hence, estabilished meadows are expected to show a similar bell-shaped growth response to fluctuations in sediment level, but with the maxima displaced towards larger burial depths than that $(4 \mathrm{~cm})$ observed here. The reason for this may be that while the resources contained within $C$. nodosa seedlings are lost upon their dead, these may be transferred to surviving neighbour shoots along the rhizomes in established meadows, thereby enhancing the growth response of survivors. However, seagrass growth response to fluctuations in sediment depth should depend on the timing of these fluctuations in relation to the seasonal pattern of seagrass growth. Shoot growth response and survivorship to burial or erosion should be lower in winter, when $C$. nodosa grows very slowly (Pérez 1989).

The increased growth of Cymodocea nodosa seedlings in response to experimental burial closely resembles the results observed for plants growing over emerged coastal dunes (e.g. Ammophila breviligulata: Disraeli 1984, Maun \& Lapierre 1984; Cakile edentula: Zhang \& Maun 1992). Plants growing over emerged coastal dunes also respond to burial by increasing their vertical growth (Disraeli 1984, Zhang \& Maun 1992), and their productivity (Eldered \& Maun 1982, Disraeli 1984, Zhang \& Maun 1990, Yuan et al. 1993). The mechanism for increased plant growth in response to burial is, however, uncertain. It was originally attributed to the increased nutrient load associated with the sediment mass deposited over the plants (Disraeli 1984). This hypothesis was, however, rejected by Zhang \& Maun (1992), who observed no difference in the growth response of plants buried by washed and amended sediments. Increased nutrient supply is also unlikely to account for the response observed here, for nutrient concentrations in the enriched sediments were sufficient to fulfil the nutritional requirements of 
C. nodosa seedlings (Pérez et al. 1991), independent of the extent of burial. Similarly, the alternative hypothesis that the growth response observed is a response to the dark conditions experienced by plants after burial has been experimentally rejected for Cakile edentula (Zhang \& Maun 1992).

Whatever the causal mechanisms, the coupling between vertical growth and sediment accretion in Cymodocea nodosa provides support for the usefulness of this species (Marbà et al. 1994a) and other seagrass species with vertical shoots (e.g. Thalassia testudinum: Patriquin 1973, 1975, Marbà et al. 1994b) as tracers of sediment dynamics. The height of the bellshaped response curve to fluctuations in sediment depth must be, however, dependent on the rate of vertical growth of the plants, and, therefore, must be species specific. Elucidating these response curves for key seagrass species is important to establish critical levels of erosion and burial the plants may tolerate and, therefore, to define conservation policies.

Acknowledgements. This work was funded by a projects of the Ramón Areces Foundation and project MAR-91-0503 of the CICYT (Spanish Government). We thank Guiomar Duarte for assistance in the field.

\section{LITERATURE CITED}

Boudouresque, C. F., Jeudy de Grissac, A., Meinesz, A. (1984). Relations entre le sedimentation et l'allongement des rhizomes orthotropes de Posidonia oceanica dans la Baie d'Elbu (Corse). In: Boudouresque, C. F., Jeudy de Grissac, A., Olivier, O. (eds.) International workshop on Posidonia oceanica beds. G.I.S. Posidonie publ. France, Marseilles, 1: 185-191

Brouns, J. J. W. M. (1985). A comparison of the annual production and biomass in three monospecific stands of the seagrass Thalassia hemprichii (Ehrenb.) Aschers. Aquat. Bot. 23: 149-175

Disraeli, D. J. (1984). The effect of sand deposits on the growth and morphology of Ammophila breviligulata. J. Ecol. 72: 145-154

This note was presented by G. W. Thayer (Senior Editorial Advisor), Beaufort, N. Carolina, USA
Duarte, C. M., Sand-Jensen, K. (1990). Seagrass colonization: patch formation and patch growth in Cymodocea nodosa. Mar. Ecol. Prog. Ser. 65: 193-200

Eldered, R. A., Maun, M. A. (1982). A multivariate approach to the problem of decline in vigour of Ammophila. Can. J. Bot. 39: 1371-1380

Gallegos, M., Merino, M., Marbà, N., Duarte, C. M. (1993). Biomass and dynamics of Thalassia testudinum in the Mexican Caribbean: elucidating rhizome growth. Mar Ecol. Prog. Ser. 95: 185-192

Marbà, N., Cebrián, J., Enríquez, S., Duarte, C. M. (1994a). Migration of large-scale subaqueous bedforms measured using seagasses (Cymodocea nodosa) as tracers. Limnol. Oceanogr. 39: 126-133

Marbà, N., Gallegos, M. E., Merino, M., Duarte, C. M. (1994b). Vertical growth of Thalassia testudinum: seasonal and interanual variability. Aquat. Bot. 47: 1-11

Marshall, J. K. (1965). Corynephorus canescens (L.) P. Beauv. as a model for the Ammophila problem. J. Ecol. 53: $447-463$

Maun, M. A., Lapierre, J. (1984). The effects of burial by sand on Ammophila breviligulata. J. Ecol. 72: 827-839

Patriquin, D. G. (1973). Estimation of growth rate, production and age of the marine angiosperm Thalassia testudinum Konig. Caribb. J. Sci. 13: 111-123

Patriquin, D. G. (1975). Migration of blowouts in seagrass beds at Barbados and Carriacou, West Indies, and its ecological and geological impications. Aquat. Bot. 1: 163-189

Pérez, M. (1989). Fanerógamas marinas en sistemas estuáricos: produción, factores limitantes y algunos aspectos del ciclo de nutrientes. Ph.D. thesis, University of Barcelona

Pérez, M., Romero, J., Duarte, C. M., Sand-Jensen, K. (1991). Phosphorus limitation of Cymodocea nodosa growth. Mar. Biol. 109: 129-133

Sokal, R. R., Rohlf, F. J. (1981). Biometry, 2nd edn. Freeman \& Co., New York

Wallen, B. (1980\}. Changes in structure and function of Ammophila during primary succession. Oikos 34: 227-238

Yuan, T., Maun, M. A., Hopkins, W. G. (1993). Effect of sand accretion on photosynthesis, leaf-water potential and morphology of two dune grasses. Funct. Ecol. 7: 676-682

Zhang. J., Maun, M. A. (1990). Effects of sand burial on seed germination, seedling emergence, survival, and growth of Agropyron psammophilum. Can. J. Bot. 68: 304-310

Zhang, J., Maun, M. A. (1992). Effects of burial in sand on the growth and reproduction of Cakile edentula. Ecography 15: $296-302$

Manuscript first received: March 30, 1993

Revised version accepted: February 8, 1994 